\title{
Analisis Tingkat Literasi Keuangan Syariah dan Dampaknya Terhadap Pendapatan Usaha Mikro di Kecamatan Siak Hulu Kabupaten Kampar, Riau
}

\author{
Oleh: Aspan Ritonga \\ (Mahasiswa Program Studi Ekonomi Syariah Program Pascasarjana (PPs) \\ Universitas Islam Negeri Sultan Syarif Kasim Riau)
}

\begin{abstract}
ABSTRAK
Untuk membuktikan terdapat atau tidaknya pengaruh faktor demografi khususnya terkait dengan gender, usia, pendidikan, lokasi usaha, jenis usaha, lama usaha, sumber modal usaha dan jumlah karyawan, terhadap tingkat literasi keuangan syariah dan dampaknya terhadap pendapatan usaha mikro di Kecamatan Siak Hulu Kabupaten Kampar Provinsi Riau diperlukan suatu kajian mendalam dalam bentuk penelitian. Peneliti telah menyebarkan angket untuk memperoleh gambaran variabel independen dalam hal demografi dan variabel dependen yakni tingkat literasi keuangan syariah serta variabel intervening terkait dengan pendapatan usaha. Data yang diperoleh secara kuantitatif deskriftif dengan instrumen kuisioner skala likert yang disebarkan kepada pelaku usaha mikro muslim di Kecamatan Siak Hulu Kabupaten Kampar Provinsi Riau dianalisis dengan menggunakan data statistik mean, model regresi linier berganda dan regresi sederhana. Berdasarkan analisis tersebut diperoleh hasil bahwa tingkat literasi keuangan syariah pelaku usaha mikro di Kecamatan Siak Hulu Kabupaten Kampar pada kategori Sufficient Literate dengan rata-rata (mean) 2,2155 atau 58 persen dari total responden. Berdasarkan hasil uji Regresi linier berganda variabel demografi berpengaruh signifikan secara simultan terhadap tingkat literasi keuangan syariah dengan $\left(\mathrm{R}^{2}\right)$ sebesar 78,5 persen, parsial hanya variabel usia, pendidikan, sumber modal usaha dan jumlah karyawan yang berpengaruh signifikan terhadap tingkat literasi keuangan syariah, sedangkan faktor gender, lokasi usaha, jenis usaha dan lama usaha tidak berpengaruh. Hasil uji Regresi sederhana menunjukkan dampak tingkat literasi keuangan syariah berpengaruh signifikan terhadap pendapatan usaha dengan $\left(\mathrm{R}^{2}\right)$ sebesar 3,9 persen, maknanya 1 persen kenaikan tingkat literasi keuangan syariah akan bertambah pendapatan usaha sebesar 3,9 persen.
\end{abstract}

Kata kunci: Demografi, literasi keuangan Syariah, dan pendapatan usaha. 


\section{PENDAHULUAN}

Pertumbuhan Usaha Mikro, Kecil dan Menengah (UMKM) sebagai penopang perekonomian suatu negara karena mampu menyerap sebagian besar tenaga kerja dan mendongkrak pendapatan masyarakat sangat menggembirakan dan perlu diberikan support dengan berbagai stimulus, baik secara kelembagaan, legacy, maupun secara finansial. Bukannya tanpa alasan yang realistik, tetapi sektor UMKM ini bahkan berkontribusi besar terhadap peningkatan produk domestik bruto (PDB).

Berdasarkan catatan Kementerian Koperasi dan UKM dalam lima tahun terakhir ini sektor UMKM tumbuh meningkat dari 57,84 persen sampai 60,34 persen. Oleh karena itu, untuk melakukan inovasi dan ekspansi usaha bahkan hanya untuk mempertahankan keberlangsungan usahanya, semestinya pelaku UMKM mengetahui dan memahami akan pengelolaan dan pemanfaatan keuangan yang efektif dan efesien. Hal ini berkaitan dengan literasi keuangan (financial literacy) para pelaku UMKM akan manajemen keuangan usahanya.

Literasi keuangan berfungsi meningkatkan kepekaan masyarakat terhadap sektor jasa keuangan, yang diawali dengan mengetahui, meyakini, terampil, dengan kata lain mencapai masyarakat yang memiliki tingkat literasi keuangan yang tinggi pada sektor jasa keuangan dalam bidang perbankan, perasuransian, lembaga pembiayaan, dana pensiun, pasar modal, dan pegadaian.

Berdasarkan hasil survey yang dilakukan oleh Otoritas Jasa Keuangan (OJK) pada tahun 2013 dengan indikator survey penelitian adalah pekerjaan, usia, gender, strata wilayah, pendidikan, dan pengeluaran. Maka terdapat hasil survey bahwa tingkat literasi keuangan penduduk Indonesia terbagi menjadi empat kategori, yaitu well literate $(21,84 \%)$, sufficient literate $(75,69 \%)$, less literate $(2.06 \%)$, dan not literate $(0,41 \%) .{ }^{1}$ Artinya, baru seperlima dari seluruh rakyat Indonesia yang teredukasi dan memiliki kepercayaan terhadap lembaga keuangan serta produk dan jasanya serta memiliki keyakinan dengan baik.

Kategori well literate berarti masyarakat telah teredukasi dan memiliki trus terhadap lembaga keuangan akan manfaat, resiko dari produk dan jasa lembaga keuangan serta trampil menggunakan produk dan jasa lembaga keuangan tersebut. Sedangkan sufficient literate artinya telah teredukasi dan memiliki kepercayaan terhadap lembaga keuangan akan manfaat, resiko dari produk dan jasa lembaga keuangan tetapi tidak trampil menggunakan produk dan jasa lembaga keuangan tersebut. Adapun less literate artinya masyarakat yang hanya teredukasi tentang lembaga keuangan, produk dan jasa keuangan, dan terakhir not literate yang berarti masyarakat tidak teredukasi dan tidak memiliki trust terhadap lembaga keuangan serta produk dan jasanya, serta tidak trampil dalam menggunakan produk dan jasa keuangan. ${ }^{2}$

Pada tahun 2016 OJK juga melakukan survey nasional dengan indikator yang sama pada tahun 2013 yang juga tentang literasi keuangan masyarakat

\footnotetext{
${ }^{1}$ Otoritas Jasa Keuangan (OJK) dikutip dari https://www.ojk.go.id/id/berita-dankegiatan/siaran-pers/Documents/Pages/Siaran-Pers-OJK-Indeks-Literasi-dan-Inklusi-KeuanganMeningkat/pdf diunduh pada Rabu, 03 April 2019, Jam 20.37 WIB.

${ }^{2}$ Ibid
} 
Indonesia. Hasilnya masyarakat Indonesia yang berada pada level well literate sebasar 29,66\%, ${ }^{3}$ dari tahun 2013-2016 literasi keuangan masyarakat Indonesia yang well literate mengalami peningkatan hanya sebesar $7,82 \%$ dalam kurun waktu tiga tahun ini.

\section{Tabel Hasil Survei Nasional OJK Literasi Keuangan Umum Tahun 2013-2016}

\begin{tabular}{|c|c|c|c|}
\hline Tahun & $\begin{array}{l}\text { Indeks Literasi } \\
\text { Keuangan }\end{array}$ & $\begin{array}{l}\text { Indeks Inklusi } \\
\text { Keuangan }\end{array}$ & $\begin{array}{c}\text { Indek Literasi Keuangan } \\
\text { Sektoral }\end{array}$ \\
\hline 2013 & $21,84 \%$ & $59,74 \%$ & $\begin{array}{ll}\text { - } & \text { Perbankan : } 21,80 \% \\
\text { - } & \text { Perasuransian : } 17,84 \% \\
\text { - } & \text { Dana Pensiun : } 7,13 \% \\
\text { - } & \text { Lembaga Pembiayaan } \\
& 9,80 \% \\
\text { - } & \text { Pergadaian : } 14,85 \% \\
\text { - } & \text { Pasar Modal : } 3,79 \%\end{array}$ \\
\hline 2016 & $29,66 \%$ & $68,82 \%$ & $\begin{array}{ll}\text { - } & \text { Perbankan : } 28,94 \% \\
\text { - } & \text { Perasuransian : } 15,76 \% \\
\text { - } & \text { Dana Pensiun : } 10,19 \% \\
\text { - } & \text { Lembaga Pembiayaan : } \\
& 13,05 \% \\
\text { - } & \text { Pergadaian : } 17,82 \% \\
\text { - } & \text { Pasar Modal : } 4,40 \%\end{array}$ \\
\hline
\end{tabular}

Perbankan syariah juga sebagai lembaga keuangan formal yang juga memberikan fasilitas-fasilitas produk pembiayaan, modal usaha, investasi dan jasa-jasa perbankan lainnya sebagaimana bank konvensional, tetapi tentu dengan mekanisme, sistem dan prinsip yang berbeda. Perbankan syariah menerapkan prinsip-prinsip syariah berdasarkan hukum Islam berlandaskan al-Qur'an dan alHadits terdiri dari : (1). Prinsip titipan atau simpanan (depository/al-wadi'ah); (2) prinsip bagi hasil (profit-sharing); (3) prinsip jual beli (sale and purchase); (4) prinsip sewa (operational lease and financial lease); (5) prinsip jasa (fee based service $)^{4}$.

Berdasarkan Undang-Undang Perbankan Syariah No. 21 Tahun 2008, menyatakan bahwa perbankan syariah adalah segala sesuatu yang menyangkut tentang bank syariah dan unit usaha syariah, mencakup kelembagaan, kegiatan usaha, serta cara dan proses dalam melaksanakan kegiatan usahanya. Bank syariah adalah bank yang menjalankan kegiatan usahanya berdasarkan prinsip syariah dan

\footnotetext{
${ }^{3}$ Ibid

${ }^{4}$ M. Syafi'i Antonio, Bank Syariah dan Teori ke Praktek, (Jakarta: Gema Insani Press, 2001), hlm. 83 .
} 
menurut jenisnya terdiri atas bank umum syariah (BUS), unit usaha syariah (UUS), dan bank pembiayaan rakyat syariah (BPRS) ${ }^{5}$.

Perbankan syariah saat ini sudah tumbuh dan berkembang yang disebut bank umum syariah (BUS) yaitu bank syariah yang berdiri sendiri sesuai dengan akta pendiriannya, seperti; Bank Muamalat Indonesia, Bank Syariah Mandiri (BSM), Bank BRI Syariah, Bank Syariah Mega, Bank Syariah Bukopin dan Bank BCA Syariah. Sedangkan unit usaha syariah merupakan unit usaha syariah yang masih dibawah pengelolaan bank konvensional. Unit usaha syariah (UUS) adalah unit kerja dari kantor pusat bank konvensional yang berfungsi sebagai kantor induk dari kantor atau unit yang melaksanakan kegiatan usaha berdasarkan prinsip syariah, atau unit kerja di kantor cabang pembantu syariah dan/atau unit syariah ${ }^{6}$. Contoh unit usaha syariah antara lain BNI Syariah, BTN Syariah, Bank Permata Syariah, BII Syariah, Bank Danamon Syariah dan Bank Riaukepri Syariah.

Berdasarkan hasil survei OJK tahun 2016, tingkat literasi dan inklusi keuangan syariah masyarkat dari setiap provinsi di Indonesia sebagai berikut:

Tabel Indeks Literasi dan Inklusi Keuangan Syariah per-Provinsi Tahun 2016

\begin{tabular}{|c|l|c|c|}
\hline No & \multicolumn{1}{|c|}{ Provinsi } & $\begin{array}{c}\text { Indeks Literasi } \\
\text { Keuangan Syariah }\end{array}$ & $\begin{array}{c}\text { Indeks Inklusi } \\
\text { Keuangan Syariah }\end{array}$ \\
\hline 1. & Aceh & $21,09 \%$ & $41,45 \%$ \\
\hline 2. & Sumatera Utara & $6,91 \%$ & $7,64 \%$ \\
\hline 3. & Sumatera Barat & $11,64 \%$ & $7,27 \%$ \\
\hline 4. & Riau & $8,73 \%$ & $8,36 \%$ \\
\hline 5. & Jambi & $12,73 \%$ & $7,27 \%$ \\
\hline 6. & Sumatera Selatan & $8,36 \%$ & $7,64 \%$ \\
\hline 7. & Bengkulu & $7,27 \%$ & $11,64 \%$ \\
\hline 8. & Bangka Belitung & $5,45 \%$ & $17,45 \%$ \\
\hline 9. & Lampung & $6,55 \%$ & $18,18 \%$ \\
\hline 10. & Kepulauan Riau & $9,82 \%$ & $8,00 \%$ \\
\hline 11. & DKI Jakarta & $16,36 \%$ & $17,45 \%$ \\
\hline 12. & Jawa Barat & $7,79 \%$ & $21,56 \%$ \\
\hline 13. & Jawa Tengah & $11,17 \%$ & $13,77 \%$ \\
\hline 14. & DI Yogyakarta & $9,45 \%$ & $13,45 \%$ \\
\hline 15. & Jawa Timur & $29,35 \%$ & $12,21 \%$ \\
\hline 16. & Banten & $7,27 \%$ & $21,09 \%$ \\
\hline 17. & Bali & $1,09 \%$ & $4,36 \%$ \\
\hline 18. & Nusa Tenggara Barat & $5,09 \%$ & $8,36 \%$ \\
\hline 19. & Nusa Tenggara & $0,00 \%$ & $5,82 \%$ \\
\hline 20. & Timur & & $6,55 \%$ \\
\hline 21. & Kalimantan Barat & $3,64 \%$ & $7,64 \%$ \\
\hline 22. & Kalimantan Tengah & $2,91 \%$ & $2,55 \%$ \\
\hline
\end{tabular}

${ }^{5}$ Ismail, Perbankan Syariah (Jakarta:Kencana Prenadamedia Group, 2011), hlm. 33. ${ }^{6}$ Ibid. 


\begin{tabular}{|c|l|c|c|}
\hline 23. & Kalimantan Timur & $3,64 \%$ & $12,36 \%$ \\
\hline 24. & Kalimantan Utara & $5,09 \%$ & $2,91 \%$ \\
\hline 25. & Sulawesi Utara & $4,00 \%$ & $5,09 \%$ \\
\hline 26. & Sulawesi Tengah & $9,45 \%$ & $3,64 \%$ \\
\hline 27. & Sulawesi Selatan & $6,18 \%$ & $14,55 \%$ \\
\hline 28. & Sulawesi Tenggara & $9,45 \%$ & $10,91 \%$ \\
\hline 29. & Gorontalo & $7,64 \%$ & $12,36 \%$ \\
\hline 30. & Sulawesi Barat & $2,55 \%$ & $2,91 \%$ \\
\hline 31. & Maluku & $2,91 \%$ & $3,27 \%$ \\
\hline 32. & Maluku Utara & $12,73 \%$ & $24,73 \%$ \\
\hline 33. & Papua Barat & $2,18 \%$ & $2,18 \%$ \\
\hline 34. & Papua & $1,09 \%$ & $5,82 \%$ \\
\hline
\end{tabular}

Sumber : Data hasil survei OJK tahun 2016

Perkembangan perbankan syariah ini sangat berpengaruh terhadap pertumbuhan UMKM karena kurangnya pengetahuan akan lembaga keuangan sebagai salah satu lembaga yang menyalurkan pembiayaan modal usaha. Hadirnya lembaga-lembaga keuangan terutama perbankan syariah diharapkan salah satu instrumen untuk peningkatan UMKM yang pada akhirnya meningkatkan kesejahteraan masyarakat Indonesia, karena jika pelaku UMKM lebih banyak dan meningkatkan usahanya akan banyak menyerap tenaga kerja dan pengangguran akan berkurang.

Berdasarkan hasil survey OJK tahun 2016, tingkat literasi keuangan masyarakat di Provinsi Riau sebesar 29,45\%, sedangkan tingkat literasi keuangan secara nasional sebesar 29,66\% artinya tingkat literasi keuangan masyarakat Riau masih dibawah secara nasional sebesar $0,21 \%$. Hal ini dapat dikategorikan tingkat literasi masyarakat provinsi Riau will literat jika dibandingkan tingkat literasi keuangan nasional.

Sedangkan tingkat literasi keuangan sektor syariah masyarakat di Provinsi Riau sebesar $8,73 \%$, sedangkan tingkat literasi keuangan sektor syariah nasional sebesar $8,11 \%$ artinya pada tingkat literasi keuangan sektor syariah masyarakat Riau lebih tinggi dari nasional sebesar $0,62 \%$. Tetapi jika dilakukan perbandingan antara tingkat literasi keuangan umum dengan tingkat literasi keuangan sektor syariah pada masyarakat provinsi Riau masih sangat rendah yaitu sebesar 20,72\%.

Salah satu dari wilayah provinsi Riau adalah kabupaten Kampar yang dijuluki dengan serambi Mekkah-nya Riau yang juga kabupaten tertua di Provinsi Riau yang berbatas langsung dengan Kota Pekanbaru sebagai ibu Kota Provinsi Riau. Hal ini tentu seharusnya memahami dan memanfaatkan lembaga keuangan syariah sebagai objek fasilitas untuk transaksi keuangannya.

Pelaku UMKM sebagai salah satu subjek yang banyak berintraksi dengan lembaga perbankan sangat diharapkan memanfaatkan jasa lembaga keuangan perbankan syariah. Berdasarkan data dari Dinas Koperasi dan UMKM Kabupaten Kampar bahwa pada tahun 2019 tercatat sebanyak 5.490 yang tersebar di 21 Kecamatan. Salah satu Kecamatan yang dekat aksesnya dengan lembaga keuangan syariah adalah kecamatan Siak Hulu. Sesuai dengan data dari Dinas Koperasi dan UMKM Kabupaten Kampar bahwa di Kecamatan Siak Hulu 
terdapat sebanyak 243 sebagai pelaku usaha mikro dan sebanyak 178 sebagai pelaku usaha kecil.

Berdasarkan kondisi ril sebagaimana yang dikemukakan sebelumnya, maka permasalahan yang akan dibahas dalam tuisan ini adalah 1) Bagaimana tingkat literasi keuangan syariah dikalangan pelaku usaha mikro di Kecamatan Siak Hulu Kabupaten Kampar? 2) Bagaimana pengaruh faktor demografi (gender, usia, pendidikan, jenis usaha, lama usaha, lokasi usaha, sumber modal dan jumlah karyawan) terhadap tingkat literasi keuangan syariah para pelaku usaha mikro di Kecamatan Siak Hulu Kabupaten Kampar secara parsial dan simultan? 3) Bagaimana pengaruh tingkat literasi keuangan syariah terhadap pendapatan para pelaku usaha mikro di Kecamatan Siak Hulu Kabupaten Kampar?

Dengan terjawabnya pertanyaan-pertanyaan di atas, maka secara teoretis tulisan ini dapat dimanfaatkan sebagai bahan kajian untuk mengembangkan analisis literasi pelaku usaha mikro di Kecamatan Siak Hulu maupun di daerah lain. Di samping itu juga dapat digunakan sebagai bahan pertimbangan bagi pelaku usaha mikro maupun bagi pemerintah sebagai pembina usaha mikro yang ada di daerah Kabupaten Kampar dalam memberikan edukasi dan kajian tentang peningkatan literasi masyarakat khususnya pelaku usaha mikro. Selanjutnya para pelaku perbankan syariah khususnya di Kecamatan Siak Hulu, Kabupaten Kampar, Riau dapat menjadikan analisis ini sebagai sumber informasi untuk bahan pertimbangan dalam pengambilan keputusan investasi dan dapat memberikan edukasi kepada masyarakat khususnya kepada pelaku usaha mikro di daerah ini.

\section{Uraian Teoretis}

Menurut OJK literasi keuangan berkaitan dengan perencanaan keuangan bagaimana cara menjalani hidup hari ini yang sederhana sesuai dengan kemampuan keuangan dan sementara itu mempersiapkan masa depan yang sejahtera. Dengan demikian literasi keuangan dipahami OJK sebagai rangkaian proses atau aktivitas untuk meningkatkan pengetahuan, keyakinan, keterampilan konsumen dan masyarakat luas sehingga mereka mampu mengelola keuangan dengan lebih baik. ${ }^{7}$

Adapun pengertian literasi keuangan syariah dapat dipahami sebagai gabungan dari ilmu pengetahuan keuangan, keahlian, minat dan perilaku yang mengikuti syariat Islam berlandaskan Al-Qur'an dan Hadits dan Ijma' serta Ijtihad para ulama yang sudah disepakati Majelis Ulama Indonesia (MUI) sebagai pembuat fatwa melalui Dewan Syariah Nasional (DSN).

Berdasarkan laporan dari UNESCO tahun 2005, menyebutkan bahwa tingkat literasi yang tinggi memberikan berbagai macam manfaat, sebagai berikut:

1) Human Benefits, literasi yang tinggi akan meningkatkan kepercayaan diri (self esteem) dan memberdayakan masyarakat. Masyarakat akan

\footnotetext{
${ }^{7} \mathrm{OJK}$, dikutip dari http://www.ojk.go.id/id/kanal/edukasi-dan-perlindungan konsumen/Pages/Literasi-Keuangan.aspx diunduh pada rabu, 3 April 2019
} 
lebih percaya diri dan dapat berkontribusi dalam kehidupan sosial kemasyarakatan.

2) Political Benefits, literasi yang tinggi akan meningkatkan pertisipasi politik masyarakat yang pada akhirnya akan meningkatkan kualitas kebijakan publik dan iklim demokrasi. Masyarakat dengan tingkat literasi yang tinggi cendrung akan menggunakan hak suaranya dan menyuarakan sikap-sikap toleransi dan nilai demkrasi.

3) Cultural benefits, bahwa program literasi akan dapat mengubah nilai, sikap, perilaku dan budaya masyarakat. Literasi yang tinggi akan menumbuhkan budaya membaca dan menulis sehingga mereka akan lebih terbuka dan mampu beradaptasi dengan perbedaan di lingkungannya.

4) Social benefits, bahwa literasi yang tinggi akan mendorong masyarakat untuk hidup secara sehat, serta mampu mendidik anak-anak mereka secara baik.

5) Economic Benefits, banyak penelitian yang menunjukkan adanya hubungan antara tingkat pendidikan dengan pertumbuhan ekonomi. Selain itu, terdapat hubungan erat antara illeracy (ketidakberaksaraan) dengan kemiskinan. Di banyak negara dengan tingkat kemiskinan tinggi, seperti Bangladesh, Ethiopia, Ghana, India, Nepal, dan Mozambik. ${ }^{8}$

Dari beberapa manfaat literasi diatas, dapat dilihat bahwa literasi masyarakat sangat penting untuk meningkatkan kepercayaan diri, menciptakan iklim lingkungan yang toleran, mendidik anak-anak dan yang tidak kalah pentingnya adalah meningkatkan pertumbuhan ekonomi individu serta cara untuk meminimalisir tingkat kemiskinan suatu negara.

Lebih lanjut, OJK membagi indikator literasi keuangan penduduk Indonesia kepada empat bagian, yaitu:

1) Well literate adalah memiliki pengetahuan dan keyakinan terhadap lembaga jasa keuangan serta produk jasa keuangan, termasuk fitur, manfaat dan resiko, hak dan kewajiban terkait produk dan jasa keuangan, serta memiliki keterampilan dalam menggunakan produk dan jasa lembaga keuangan tersebut.

2) Sufficient literate adalah memiliki pengetahuan dan keyakinan tentang lembaga jasa keuangan serta produk dan jasa keuangan, termasuk fitur, manfaat, resiko dari produk dan jasa keuangan.

3) Less literate adalah hanya memiliki pengetahuan tentang lembaga jasa keuangan, produk dan jasa keuangan.

4) Not literate adalah tidak memiliki pengetahuan dan keyakinan terhadap lembaga keuangan serta produk dan jasanya, serta tidak memiliki keterampilan dalam menggunakan produk dan jasa keuangan. ${ }^{9}$

\footnotetext{
${ }^{8}$ Lihat Kusumaningtuti S. Soetiono dan Cecep Setiawan, Literasi dan Inklusi Keuangan Indonesia, (Depok: Rajawali Pers), 2018.

${ }^{9}$ Diana Djuwita dan Ayus Ahmad Yusuf, Diana Djuwita dan Ayus Ahmad Yusuf; Tingkat Literasi Keuangan Syariah di Kalangan UMKM dan Dampaknya terhadap Perkembangan Usaha,
} 
Sementara itu Oseifuah, Emmanuel Kojo (2010) menyebutkan ada tiga indikator literasi keuangan (Financial Literacy) yaitu:

1) Financial Knowledge, yaitu memiliki pengetahuan mengenai terminologi-terminologi keuangan.

2) Financial Attitudes, yaitu ketertarikan atau minat dalam memperbaiki pengetahuan keuangan.

3) Financial Behaviour, yaitu perilaku yang berorientasi untuk berbelanja (spending) dan atau menabung (saving).

Adapun menurut Lusardi dan Mitchell (2009), menyebutkan dalam penelitiannya bahwa indikator literasi keuangan pada dua tahap yaitu:

a) Tahap dasar, yaitu meliputi pengetahuan mengenai matematika, tingkat suku bunga, inflasi, nilai waktu uang dan tipuan nilai uang.

b) Tahap lanjutan, yaitu meliputi pengetahuan tentang pasar saham dan fungsinya, reksadana, tingkat suku bungan acuan dan kaitannya dengan obligasi, perusahaan pengelola keuangan, pengetahuan tentang resiko-resiko finansial apabila menginvestasikan uangnya pada berbagai pilihan investasi saham atau obligasi, tingkat pengembalian uang jangka panjang, fluktuatif atau ketidakpastian yang tinggi, dan diversifikasi resiko.

Perlu dipahami bahwa tingkat literasi keuangan yang dimiliki setiap individu tentunya berbeda-beda. Hal tersebut disebabkan oleh faktor-faktor yang mempengaruhinya sehingga terjadi perbedaan yang signifikan antara individuindividu lainnya. Adapun faktor-faktor yang mempengaruhi literasi keuangan adalah:

1) Faktor Perilaku Keuangan (Financial Behavior).

Financial Behavior berhubungan dengan tanggung jawab keuangan seseorang terkait dengan cara pengelolaan keuangan. Menurut Hilgert, Jeanne and Sandra (2003), menyebutkan bahwa perilaku keuangan seseorang akan tampak dari seberapa bagus seseorang mengelola uang kas, mengelola utang, tebungan dan pengeluaran-pengeluaran lain.

2) Faktor Demografi.

Dalam hal ini dikatakan bahwa perempuan dan etnis minoritas memiliki pengetahuan keuangan yang rendah, sementara menurut Monticone, Chaira (2010), menyatakan bahwa laki-laki memiliki pengetahuan keuangan dan ekonomi makro yang baik.

3) Faktor Pendidikan

Variabel pendidikan sebagai human capital merupakan salah satu variabel yang diharapkan akan memberikan efek terhadap kesejahteraan seseorang. Pendidikan berpengaruh pada produktifitas dan efisiensi kerja seseorang yang kemudian akan mempengaruhi real income individu atau rumah tangga (Rhamatia, 2004).

4) Latar Belakang Keluarga

http://syekhnurjati.ac.id/jurnal/index.php/amwal/article/view/2837, diakses pada Rabu tanggal 3 April 2019 jam 19.59 WIB. 
Selain demografi dan kemampuan kognitif, literasi keuangan juga dilatar belakangi oleh keluarga seperti pendidikan orang tua terutama ibu. Jadi pendidikan yang diperoleh dari orang tua atau keluarga dapat mempengaruhi pengetahuan keuangan seseorang (Tasya Desiyana, 2015).

5) Jenis Kelamin

Chen dan Vope (1998) menemukan bahwa dalam hal financial literacy pada tingkat umum perempuan lebih rendah dari pada lakilaki. Hal ini juga ditemukan oleh Lalonde dan Schmidt (2010) memperkuat temuan yang menyatakan bahwa literasi keuangan bentuk pengetahuan umum pada laki-laki lebih tinggi dibandingkan perempuan. $^{10}$

\section{Kerangka Pemikiran}

Untuk mengukur tingkat literasi keuangan seseorang dapat dilakukan dengan indikator pengetahuan keuangan (financial knowledge), perilaku keuangan (financial behaviour), dan sikap keuangan (financial attitude). Sebagaiamana yang dikemukaan oleh Oseifuah, Emmanuel Kojo (2010), ada tiga indikator literasi keuangan (Financial Literacy) yaitu:

1. Financial Knowledge, yaitu memiliki pengetahuan mengenai terminologiterminologi keuangan.

2. Financial Attitude, yaitu ketertarikan atau minat dalam memperbaiki pengetahuan keuangan.

3. Financial Behaviour, yaitu perilaku yang berorientasi untuk berbelanja (spending) dan atau menabung (saving).

Dalam penelitian ini, sesuai dengan telaah pustaka dapat disusun logika kerangka berpikir bahwa tingkat literasi keuangan seseorang dipengaruhi oleh pemahaman keuangan (Financial Knowledge), perilaku (financial behavior), dan minat (financial attitude). Maka sebagai indikator utama, peneliti menjadikan dari ketiga indikator diatas sebagai instrumen mengukur tingkat literasi keuangan para pelaku usaha mikro tentang tingkat literasi keuangan syariah dan dampaknya terhadap pendapatan usaha ekonomi mikro di Kecamatan Siak Hulu Kabupaten Kampar.

Indikator-indikator diatas akan diuji faktor-faktor apa saja yang mempengaruhinya, dalam operasionalnya disebut sebagai variabel independen $\left(\mathrm{X}_{1}, \mathrm{X}_{2}, \ldots . . \mathrm{X}_{\mathrm{k}}\right)$. Maka peneliti menetapkan variabel bebas (independen) disebut faktor demografi yaitu gender, usia, pendidikan, lokasi usaha, jenis usaha, lama usaha, sumber modal usaha, dan jumlah karyawan.

Sedangkan variabel dependen $(\mathrm{Y})$ yaitu tingkat literasi dalam pengetahuan keuangan (financial knowledge), perilaku pengelolaan keuangan (financial behaviour) dan sikap terhadap pengelolaan keuangan (financial attitude), selanjutnya diuji pengaruh tingkat literasi keungan syariah (Y) terhadap pendapatan pelaku usaha mikro yang disebut variabel intervening $(\mathrm{Z})$.

\footnotetext{
${ }^{10}$ Susie Suryani dan Surya Ramadhan; "Analisis Literasi Keuangan Pada Pelaku Usaha Mikro di Kota Pekanbaru”, https://journal.ipm2kpe.or.id/index.php/COSTING/article/view/67/3, diakses pada Rabu, 3 April 2019 jam 20.16 WIB
} 
Gambaran kerangka berfikir yang digunakan adalah sebagai berikut:

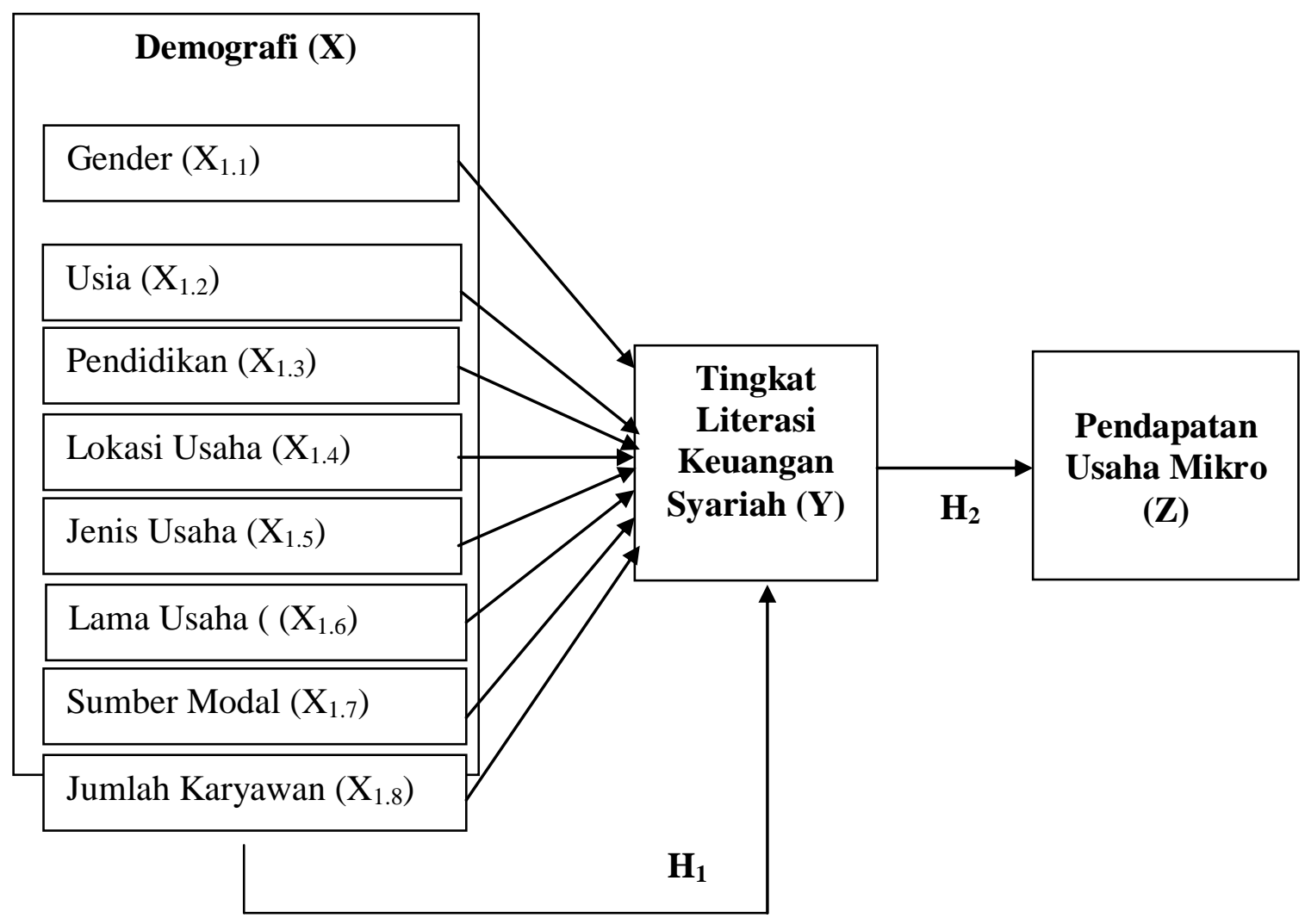

Gambar di atas adalah skema berpikir untuk mengukur pengaruh faktor demografi (gender, usia, pendidikan, lokasi usaha, jenis usaha, lama usaha, sumber modal usaha dan jumlah karyawan) terhadap tingkat literasi keuangan syariah pelaku usaha mikro secara parsial dan simultan, dan seterusnya pengaruh tingkat literasi keuangan syariah terhadap pendapatan usaha para pelaku usaha Mikro di Kecamatan Siak Hulu Kabupaten Kampar.

\section{Konsep Operasional}

Konsep operasional dari masing-masing variabel akan dijelaskan sebagai berikut :

\begin{tabular}{|c|c|c|c|}
\hline Variabel & Defenisi & Dimensi & $\begin{array}{c}\text { Skala } \\
\text { Kuesioner }\end{array}$ \\
\hline $\begin{array}{c}\mathrm{X} \\
\text { (Demografi) }\end{array}$ & $\begin{array}{l}\text { Demografi adalah ilmu } \\
\text { yang mempelajari } \\
\text { dinamika kependudukan } \\
\text { manusia yang meliputi } \\
\text { ukuran, struktur, dan } \\
\text { distribusi penduduk, serta } \\
\text { bagaimana jumlah } \\
\text { penduduk berubah setiap }\end{array}$ & $\begin{array}{l}\text { - Gender }\left(\mathrm{X}_{1.1}\right) \\
\text { - Usia }\left(\mathrm{X}_{1.2}\right) \\
\text { - Pendidikan }\left(\mathrm{X}_{1.3}\right) \\
\text { - Lokasi usaha }\left(\mathrm{X}_{1.4}\right) \\
\text { - Jenis usaha }\left(\mathrm{X}_{1.5}\right) \\
\text { - Lama usaha }\left(\mathrm{X}_{1.6}\right) \\
\text { - Sumber modal }\left(\mathrm{X}_{1.7}\right) \\
\text { - Jumlah karyawan }\left(\mathrm{X}_{1.8}\right)\end{array}$ & Ordinal \\
\hline
\end{tabular}




\begin{tabular}{|c|c|c|c|}
\hline & $\begin{array}{l}\text { waktu akibat kelahiran, } \\
\text { kematian, migrasi, serta } \\
\text { penuaan. }{ }^{11}\end{array}$ & & \\
\hline $\begin{array}{c}\mathrm{Y} \\
\text { (Literasi) }\end{array}$ & $\begin{array}{l}\text { Literasi keuangan adalah } \\
\text { sebagai gabungan dari } \\
\text { kemampuan } \\
\text { (awareneness), ilmu } \\
\text { pengetahuan } \\
\text { (knowledge), keahlian } \\
(\text { skills), minat dan } \\
\text { perilaku (attitude and } \\
\text { behaviours) yang } \\
\text { diperlukan ryntuk } \\
\text { membuat keputusan } \\
\text { keuangan yang sehat } \\
\text { pada akhirnya mencapai } \\
\text { kesejahteraan keuangan } \\
\text { individu. }{ }^{12}\end{array}$ & $\begin{array}{ll}\text { - } & \text { Financial knowledge } \\
\text { - } & \text { Financial behaviour } \\
\text { - } & \text { Financial attitude }\end{array}$ & $\begin{array}{l}\text { Skala } \\
\text { Likert }\end{array}$ \\
\hline $\begin{array}{c}\mathrm{Z} \\
\text { (Pendapatan) }\end{array}$ & $\begin{array}{l}\text { Pendapatan adalah } \\
\text { jumlah uang yang } \\
\text { diterima oleh perusahaan } \\
\text { dari aktivitasnya, } \\
\text { kebanyakan dari } \\
\text { penjualan produk } \\
\text { dan/atau jasa kepada } \\
\text { pelanggan. }{ }^{13}\end{array}$ & $\begin{array}{ll}\text { - } & \text { Modal awal usaha } \\
\text { - } & \text { Harga pokok produksi } \\
\text { - } & \text { Laba bersih }\end{array}$ & $\begin{array}{c}\text { Ordinal/ } \\
\text { Likert }\end{array}$ \\
\hline
\end{tabular}

Variabel yang digunakan terdiri dari tiga jenis variabel, yaitu:

1. Variabel Independen (X)

Variabel independe yaitu variabel yang menjadi sebab terjadinya atau terpengaruhinya variabel dependen. Variabel independen dalam penelitian ini adalah gender, usia, pendidikan, lokasi usaha, jenis usaha, lama usaha, sumber modal usaha, dan jumlah karyawan (demografi).

Untuk penyusunan instrumen peneliti mengadopsi penelitian Diana Djuwita (2018) kemudian dikembangkan oleh peneliti disesuaikan dengan kebutuhan dari peneliti.

2. Variabel Dependen (Y)

Variabel dependen sering disebut dengan variabel terikat yaitu variabel yang disebabkan atau dipengaruhi oleh adanya variabel bebas/variabel independen. Besarnya perubahan pada variabel dependen

\footnotetext{
${ }^{11}$ https://id.wikipedia.org/wiki/Demografi diakses pada hari selasa, 5 November 2019, pukul 7,58 Wib.

${ }^{12}$ Kusumaningtuti S. Soetiono dan Cecep Setiawan., Literasi dan Inklusi, hlm. 7.

${ }^{13}$ https://id.wikipedia.org/wiki/Demografi diakses pada hari selasa, 5 November 2019, pukul 7,58 Wib.
} 
targantung dari besarnya variabel bebas atau independen. Variabel dependen dalam penelitian ini adalah tingkat literasi pelaku usaha ekonomi mikro dengan indikator tingkat pengetahuan tentang keuangan (financial knowledge), perilaku dalam pengelolaan keuangan (financial behaviour) dan keinginan dan minat mempergunakan keuangan (financial attitude).

Penyusunan instrumen untuk variabel ini juga diadopsi dari Diana Djuwita (2018) dan Zara Fathia Muflihani (2015) kemudian dikembangkan oleh peneliti disesuaikan dengan kebutuhan dari peneliti.

3. Variabel Intervening $(\mathrm{Z})$

Variabel intervening adalah variabel yang berfungsi menghubungkan variabel satu dengan variabel yang lain. Hubungan itu dapat menyangkut sebab akibat atau hubungan pengaruh dan terpengaruh. Maka variabel intervening dalam penelitian ini adalah mangukur pengaruh tingkat literasi terhadap pendapatan para pelaku usaha ekonomi mikro.

Penyusunan instrumen untuk variabel ini juga diadopsi dari Karana Haikal (2014) kemudian dikembangkan oleh peneliti disesuaikan dengan kebutuhan dari peneliti. Dalam penelitian ini hanya mengambil klasifikasi modal usaha, harga pokok produksi dan laba bersih yang menunjukkan pendapatan pada periode tertentu.

\section{Hipotesis}

Hipotesis adalah jawaban atau dugaan sementara yang harus diuji kebenarannya. ${ }^{14}$ Beberapa kajian literatur-literatur sebelumnya, maka hipotesis yang dapat dikembangkan adalah:

$\mathrm{H}^{1}$ : Faktor demografi (gender, usia, pendidikan, lokasi usaha, jenis usaha, lama usaha, sumber modal, dan jumlah karyawan) terdapat pengaruh signifikan terhadap tingkat literasi keuangan syariah para pelaku usaha mikro di Kecamatan Siak Hulu Kabupaten Kampar.

$\mathrm{H}^{2}$ : Tingkat literasi keuangan syariah para pelaku usaha mikro berpengaruh signifikan terhadap pendapatan usaha mikro di Kecamatan Siak Hulu Kabupaten Kampar.

\section{Hasil dan Pembahasan}

\section{Tingkat Literasi Keuangan Syariah Para Pelaku Usaha Mikro di Kecamatan Siak Hulu Kabupaten Kampar}

Pada permasalahan pertama dipertanyakan tentang bagaimana tingkat literasi keuangan syariah para pelaku usaha mikro di Kecamatan Siak Hulu Kabupaten Kampar. Kalsifikasi tingkat literasi keuangan menurut OJK ada empat kategori yaitu yaitu well literate, sufficient literate, less literate, dan not literate. ${ }^{15}$

\footnotetext{
${ }^{14}$ Sofyan Siregar, Statistik Prametrik untuk Penelitian Kuantitatif, (Jakarta: PT. Bumi Aksara, 2013), hlm. 65.

${ }^{15}$ Otoritas Jasa Keuangan (OJK), dalam https://www.ojk.go.id/id/berita-dankegiatan/siaran-pers/Documents/Pages/Siaran-Pers-OJK-Indeks-Literasi-dan-Inklusi-KeuanganMeningkat/pdf diakses pada Rabu, 03 April 2019, Jam 20.37 WIB.
} 
Berdasarkan hasil hasil analisis didapatkan bahwa tingkat literasi keuangan syariah para pelaku usaha mikro di Kecamatan Siak Hulu Kabupaten Kampar dari 143 sampel responden penelitian diperoleh hasilnya yaitu sebanyak 20 orang (14\%) well literate, 85 orang (59\%) sufficient literate, 29 orang (20\%) less literate, dan 9 orang $(6 \%)$ not literate.

Sesuai dengan hasil diatas bahwa tingkat literasi keuangan syariah pelaku usaha mikro di kecmatan siak hulu kabupaten kampar berada pada kategori sufficient literate. Artinya para pelaku usaha mikro di Kecamatan Siak Hulu ini telah mengetahui sebagian istilah dan produk sistem syariah, tetapi tidak termotivasi dan memanfaatkan fasilitas ini baik dalam kegiatan usahanya maupun dalam memperoleh modal usahanya dari lembaga keuangan syariah.

Hasil penelitian ini sejalan dengan penelitian yang dilakukan oleh Susie Suryani (2017) dengan judul Analisis Literasi Keuangan Pada Pelaku Usaha Mikro di Kota Pekanbaru, dimana hasil penelitiannya menyebutkan tingkat literasi keuangan pelaku usaha mikro di Kota Pekanbaru barada pada kategori sedang $(57,9 \%)^{16}$. Berbeda dengan penelitian yang dilakukan oleh Mustika Widiowati (2017) dengan judul Literasi Keuangan Pelaku UMKM Kota Semarang, bahwa tingkat literasi pelaku UMKM di Kota Semarang mayoritas pada kategori Not Literate $(36 \%)^{17}$. Penelitian Diana Djuwita (2018) dengan judul Tingkat Literasi Keuangan Syariah di Kalangan UMKM dan Dampaknya terhadap Perkembangan Usaha di Kota Cirebon, yang memperoleh hasil tingkat literasi keuangan syariah UMKM di Kota Cirebon pada kategori Less literate. ${ }^{18}$

\section{Pengaruh Faktor Demografi Parsial terhadap Tingkat Literasi Keuangan Syariah pada pelaku Usaha Mikro di Kecamatan Siak Hulu Kabupaten Kampar}

Pada rumusan masalah yang kedua, yaitu bagaimana pengaruh faktor Demografi (Gender, Usia, Tingkat Pendidikan, Lokasi usaha, Jenis Usaha, Lama Usaha, Sumber modal usaha dan Jumlah Karyawan) terhadap Tingkat Literasi Keuangan Syariah para pelaku usaha mikro di Kecamatan Siak Hulu Kabupaten Kampar.

Berdasarkan hasil uji regresi berganda secara parsial maupun simultan terdapat pengaruh yang signifikan variabel Faktor Demografi Terhadap Tingkat Literasi Keunangan Syariah Pada Pelaku Usaha Mikro di Kecamatan Siak Hulu Kabupaten Kampar. Hasil Uji Regresi Berganda Secara Parsial variabel yang

\footnotetext{
${ }^{16}$ Susie Suryani dan Surya Ramadhan; “Analisis Literasi Keuangan Pada Pelaku Usaha Mikro di Kota Pekanbaru”, https://journal.ipm2kpe.or.id/index.php/COSTING/article/view/67/3, diakses pada Rabu, 3 April 2019 jam 20.16 WIB

${ }^{17}$ Mustika Widowati dan Winarto; "Literasi Keuangan Pelaku UMKM Kota Semarang”,http://jurnal.poliupg.ac.id/index.php/infak diakses pada Rabu tanggal 3 April 2019 jam 19.50 WIB, hln. 15.

${ }^{18}$ Diana Djuwita dan Ayus Ahmad Yusuf, Diana Djuwita dan Ayus Ahmad Yusuf; Tingkat Literasi Keuangan Syariah di Kalangan UMKM dan Dampaknya terhadap Perkembangan Usaha, http://syekhnurjati.ac.id/jurnal/index.php/amwal/article/view/2837, diakses pada Rabu tanggal 3 April 2019 jam 19.59 WIB.
} 
berpengaruh signifikan yaitu pada Usia, Tingkat Pendidikan, Sumber modal usaha dan Jumlah Karyawan. Sedangkan pada variabel Gender, Lokasi Usaha, Jenis Usaha dan Lama Usaha tidak berpengaruh terhadap tingkat literasi keuangan syariah para pelaku usaha mikro di Kecamatan Siak Hulu Kabupaten Kampar. bawah ini:

Jika diilustrasikan dalam sebuah tabel, maka dapat dilihat sebagaimana di

Tabel Hasil Uji Regresi Linier Berganda Varibel $\mathbf{X}_{1.1}-\mathbf{X}_{1.8}$

\begin{tabular}{|l|l|r|r|l|}
\hline No & \multicolumn{1}{|c|}{ Nama Variabel } & \multicolumn{1}{|c|}{$\begin{array}{c}\text { Hasil Uji } \\
\text { Regresi ( t })\end{array}$} & \multicolumn{1}{c|}{$\begin{array}{c}\text { Hasil Uji } \\
\text { Regresi } \\
\text { ( Sig })\end{array}$} & \multicolumn{1}{|c|}{ Ket } \\
\hline 1. & Gender $\left(\mathrm{X}_{1.1}\right)$ & 1.176 & .242 & $\begin{array}{l}\text { Tidak Berpengaruh } \\
\text { Signifikan }\end{array}$ \\
\hline 2. & Usia $\left(\mathrm{X}_{1.2}\right)$ & 5.891 & .000 & Berpengaruh Signifikan \\
\hline 3. & Pendidikan $\left(\mathrm{X}_{1.3}\right)$ & .5 .221 & .000 & Berpengaruh Signifikan \\
\hline 4. & Lokasi Usaha $\left(\mathrm{X}_{1.4}\right)$ & .480 & .437 & $\begin{array}{l}\text { Tidak Berpengaruh } \\
\text { Signifikan }\end{array}$ \\
\hline 5. & Jenis Usaha $\left(\mathrm{X}_{1.5}\right)$ & .022 & .973 & $\begin{array}{l}\text { Tidak Berpengaruh } \\
\text { Signifikan }\end{array}$ \\
\hline 6. & Lama Usaha $\left(\mathrm{X}_{1.6}\right)$ & 6.172 & .000 & Sidak Berpengaruh \\
\hline 7. & $\begin{array}{l}\text { Sumber Modal } \\
\text { Usaha }\left(\mathrm{X}_{1.7}\right)\end{array}$ & 2.408 & .017 & Berpengarikan \\
\hline 8. & $\begin{array}{l}\text { Jumlah Karyawan } \\
\left(\mathrm{X}_{1.8}\right)\end{array}$ & & & \\
\hline
\end{tabular}

Sedangkan hasil nilai Uji t statistik dan nilai probabilitas pada tabel diatas menunjukkan bahwa dalam penelitian ini, variabel Demografi yang meliputi variabel Gender, Usia, Tingkat Pendidikan, Lokasi usaha, Jenis Usaha, Lama Usaha, Sumber modal dan Jumlah Karyawan secara parsial ada beberapa yang berpengaruh terhadap Literasi Keuangan Syariah.

Variabel Gender ditemui tidak memiliki pengaruh yang signifikan terhadap tingkat literasi keuangan responden, hal ini dibuktikan dengan nilai probabilitasnya yang besar $(>$ ) dari batasan nilai kritis yang ditetapkan dalam penelitian ini yaitu sebesar 0.05. Fakta dan temuan ini mengindikasikan bahwa gender bukanlah faktor penentu tingkat literasi keuangan syariah seseorang baik atau buruknya. Adanya kesetaraan gender saat ini membuat setiap orang (laki-laki atau perempuan) bebas dalam memperoleh akses pendidikan formal maupun non formal.

Variabel Usia memiliki pengaruh yang signifikan terhadap tingkat literasi keuangan responden, hal ini dapat dilihat dari nilai probabilitas yang diperoleh dari penelitian ini sebesar $0.000<$ alpha $=0.05$. dengan nilai $\mathrm{t}$ hitung sebesar $5.891>1.655$. dengan demikian Ho ditolak dan Ha diterima, hipotesis yang diajukan diterima, dan dinyatakan bahwa variabel usia memberikan pengaruh yang signifikan terhadap tingkat literasi keuangan responden. Pengaruh usia terhadap tingkat literasi keuangan syariah responden penulis berkeyakinan bahwa pengalaman dan pengetahuan dari pelaku usaha mikro yang sudah memiliki usia matang membuat mereka lebih banyak belajar yang bersumber dari informasi dan 
pengalaman hidupnya. Pengaruh usia ini mengindikasikan bahwa semakin tinggi atau matang usia seseorang, maka akan semakin tinggi tingkat literasi mereka terhadap pengelolaan keuangan.

Variabel pendidikan dalam penelitian ini memiliki pengaruh yang signifikan terhadap tingkat literasi keuangan syariah pelaku usaha mikro. Hal ini dibuktikan dengan nilai probabilitas dari hasil analisis regresi sebesar $0.000<$ alpha 0.05 , dengan nilai t hitung sebesar -5.221 dan koefisien regresi sebesar 0.376. Hasil penelitian ini menunjukan adanya pengaruh signifikan negatif dari tingkat pendidikan terhadap tingkat literasi keuangan syariah responden. Bahwa semakin tinggi jenjang pendidikan seseorang, maka akan semkin tinggi tingkat literasi keuangan syariah dari responden tersebut. Ini menunjukan bahwa pendidikan formal memiliki peran yang penting dalam membentuk tingkat literasi keuangan syariah seseorang.

Pada variabel lokasi usaha, dari hasil penelitian ini, tidak diperoleh pengaruh yang signifikan terhadap tingkat literasi keuangan syariah sesorang. Hal ini dibuktikan dengan nilai probabilitasnya sebesar $0.437>$ alpha 0.05 . Fakta penelitian ini bisa di interprestasikan bahwa fenomena lokasi usaha sama sekali tidak menentukan tingkat literasi keuangan syariah seseorang, sebab pemilihan lokasi adalah faktor kesempatan dan peluang seseorang, kemungkinan bisa saja memilih tempat usaha yang cocok dengan jenis usahanya yang sesuai menurut analisanya, namun kesempatan, modal yang terbatas bisa jadi sebagai hambatan untuk memperoleh lokasi usaha yang strategis.

Variabel Jenis Usaha, bahwa variabel ini juga tidak memiliki pengaruh yang signifkan terhadap tingkat literasi keuangan syariah seseorang. Hasil penelitian ini membuktikan bahwa nilai probabilitasnya sebesar $0.673>$ alpha 0.05 , jenis usaha yang digeluti oleh pelaku usaha mikro tidak berpengaruh terhadap tingkat literasinya, artinya apapun jenis usaha yang sedang digeluti oleh responden sama sekali tidak menentukan tinggi atau rendahnya tingkat literasi keuangan syariah mereka.

Varibel lama usaha, dalam hasil penelitian ini juga tidak menunjukan hasil yang signifikan, hal ini dibuktikan dengan hasil nilai probabilitas dari penelitian sebesar $0.982>$ alpha 0.05. maka peneliti berasumsi bahwa lama usaha seseorang pelaku usaha mikro dalam menjalani usaha sama sekali tidak berpengaruh terhadap tingkat literasi keuangan syariahnya.

Adapun variabel sumber modal usaha dan jumlah karyawan, dari hasil penelitian ini memiliki pengaruh yang signifikan terhadap tingkat literasi keuangan syariah responden, hal ini dibuktikan dengan nilai perolehan probabilitas masing-masing sebesar 0.000 dan 0.017 yang > alpha 0.05. Hal ini menurut hemat peneliti sangat erat hubungan sumber modal usaha dengan tingkat literasi keuangan syariah seseorang karena semakin baik pengelolaan keuangan seseorang maka sumber modal usaha juga akan semakin mudah diperoleh baik dari pihak ketiga maupun dari lembaga keuangan seperti perbankan, koperasi dan lain-lain. Begitu juga dengan variabel jumlah karyawan, semakin pandai seseorang dalam mengatur karyawan dan keuangan akan semakin maju usahanya.

Hasil penelitian ini sebagian sejalan dengan penelitian yang dilakukan oleh Susie Suryani (2017), yang menyebutkan bahwa variabel yang 
mempengaruhi tingkat literasi keuangan pelaku UMKM di Kota Pekanbaru adalah tingkat pendidikan dan pendapatan, sedangkan perbedaan gender dan usia tidak berpengaruh terhadap tingkat literasi keuangan UMKM di Kota Pekanbaru ${ }^{19}$. Sedangkan penelitian Diana Djuwita (2018), variabel lama usaha dan jumlah karyawan yang mempengaruhi Tingkat Literasi Keuangan Syariah di Kalangan UMKM di Kota Cirebon, untuk dampak perkembangan usaha variabel demografi mempengaruhi variabel $\mathrm{Y}_{1}$ (financial behavior) $^{20}$.

Adapun hasil analisa pengaruh simultan variabel demografi terhadap tingkat literasi keuangan syariah adalah berpengaruh sifnifikan. Berdasarkan hasil uji regresi berganda simultan pada anova tabel 4.5.4 nilai signifikansi dari hasil penelitian sebesar $0.000<$ alpha 0.05 dan di dapat nilai $F$ hitung sebesar 61.160 ( $>$ dari nilai $\mathrm{F}$ tabel). hal ini membuktikan bahwa adanya pengaruh secara bersama-sama (Simultan) antara variabel gender, usia, tingkat pendidikan, lokasi usaha, jenis usaha, lama usaha, sumber modal dan jumlah karyawan terhadap tingkat literasi keuangan responden.

Sedangkan koefisien determinasi $\left(\mathrm{R}^{2}\right)$ variabel demografi secara simultan dapat menjelaskan tingkat literasi keuangan syariah responden sebesar 0,785, artinya 78,5 persen varibel demografi mempengaruhi varibel Y (tingkat literasi keuangan syariah) responden dan sebesar 21,5 persen lagi variabel lain yang tidak dijelaskan pada penelitian ini.

Variabel-variabel penelitian ini sejalan dengan survei OJK di seluruh Provinsi (34 Provinsi) dan $64 \mathrm{kota} /$ kabupaten tentang tingkat literasi keuangan dan inklusi keuangan tahun 2016, yang mengelompokkan responden menjadi beberapa klaster untuk mencerminkan karakteristik masyarakat Indonesia yaitu : gender (jenis kelamin), usia, tingkat pendidikan, jenis pekerjaan, tingkat pengeluaran, dan strata wilayah. ${ }^{21}$ Jika dibandingkan dengan penelitian ini ada lima karakteristik oleh OJK dan peneliti jadikan sebagai varibel yaitu gender, usia, tingkat pendidikan, jenis usaha (jenis pekerjaan) dan lokasi usaha (strata wilayah). Ini menunjukkan bahwa variabel penelitian ini sebagian juga di jadikan sebagai variabel pada penelitian lainnya.

\section{Dampak Tingkat Literasi Keuangan Syariah terhadap Pendapatan.}

Rumusan masalah ketiga dalam penelitian ini adalah bagaimana pengaruh tingkat literasi keuangan syariah terhadap pendapatan usaha mikro di Kecamatan Siak Hulu Kabupaten Kampar. Berdasarkan hasil uji statistik regresi sederhana bahwa tingkat literasi keuangan syariah terhadap pendapatan usaha mikro di Kecamatan Siak Hulu Kabupaten Kampar berpengaruh signifikan.

\footnotetext{
${ }^{19}$ Susie Suryani dan Surya Ramadhan; "Analisis Literasi Keuangan Pada Pelaku Usaha Mikro di Kota Pekanbaru”, https://journal.ipm2kpe.or.id/index.php/COSTING/article/view/67/3, diakses pada Rabu, 3 April 2019 jam 20.16 WIB.

${ }^{20}$ Diana Djuwita dan Ayus Ahmad Yusuf, Diana Djuwita dan Ayus Ahmad Yusuf; Tingkat Literasi Keuangan Syariah di Kalangan UMKM dan Dampaknya terhadap Perkembangan Usaha, http://syekhnurjati.ac.id/jurnal/index.php/amwal/article/view/2837, diakses pada Rabu tanggal 3 April 2019 jam 19.59 WIB

${ }^{21}$ Kusumaningtuti S. Soetiono, Literasi dan Inklusi, hln. 78.
} 
Hasil uji regresi sederhana dalam penelitian ini adalah terdapat pengaruh yang signifikan antara Literasi Keuangan syariah (Y) terhadap Pendapatan usaha (Z). Berdasarkan hasil olahan data pada tabel sebelumnya dapat dilihat bahwa tingkat probabilitasnya sebesar $0.018<\alpha=0,05$, dengan $\mathrm{t}$ hitung $>\mathrm{t}$ tabel (2.395>1.655), maka hipotesisnya Ho ditolak dan Ha diterima, maka dapat disimpulkan bahwa terdapat pengaruh signifikan antara variable Literasi keuangan syariah (Y) terhadap Pendapatan usaha (Z).

Adapun besaran pengaruh variabel $\mathrm{Y}$ terhadap variabel $\mathrm{Z}$ dapat dilihat pada tabel table 4.5.7 diatas bahwa nilai $\mathrm{R}$ Square $=0.39$ artinya 39 persen variabel Literasi Keuangan Syariah (Y) dapat mempengaruhi variabel Pendapatan usaha $(\mathrm{Z})$ dan sisanya dijelaskan dan dipengaruhi oleh variabel lain yang tidak dijelaskan dalam penelitian ini. Penulis menyimpulkan bahwa berdasarkan hasil penelitian diatas dapat di buat perbandingan $1: 0,39$ ( 1 persen kenaikan tingkat literasi keuangan syariah responden 3,9 persen kenaikan pendapatan usahanya), semakin tinggi tingkat literasi keuangan seseorang akan semakin tinggi pula pendapatan usahanya.

Hasil penelitian ini sesuai dengan pernyataan Robert F. Duvall, (President dari the National Council on Economic Edukation, USA), menyebutkan bahwa "Economic literacy is a vital skill, just as vital as reading literacy" (Duvall, 1998). Masyarakat dengan tingkat literasi keuangan yang tinggi berpotensi memberikan nilai produktivitas yang lebih tinggi. ${ }^{22}$ Susie Suryani (2017), yang menyebutkan dalam penelitiannya terdahulu bahwa variabel yang mempengaruhi tingkat literasi keuangan pelaku UMKM di Kota Pekanbaru adalah tingkat pendidikan dan pendapatan ${ }^{23}$

\section{Penutup}

Berdasarkan hasil analisis yang dilakukan dengan empat klasifikasi yaitu kategori Will Literate, Sufficient Literate, Less Literate dan Not Literate, maka diperoleh hasil rata-rata tingkat literasi keuangan responden sebesar 2.3155,sehingga dapat disimpulkan bahwa tingkat literasi keuangan responden dikatakan berada pada kategori Sufficient Literate. Sedangkan jika dilihat secara parsial diperoleh hasil bahwa masing-masing faktor usia, pendidikan, sumber modal dan jumlah Karyawan secara berpengaruh signifikan terhadap tingkat Literasi Keuangan Syariah responden. Adapun untuk faktor gender, lokasi usaha, jenis usaha dan lama usaha tidak berpengaruh terhadap tingkat Literasi Keuangan Syariah responden.

Sebanyak 78.5 persen variabel literasi keuangan dipengaruhi oleh variabel demografi yang meliputi gender, usia, pendidikan, lokasi usaha, jenis usaha, lama usaha, sumber modal dan jumlah karyawan. Sementara itu sebesar 21.5 persen tingkat literasi keuangan responden dipengaruhi oleh variabel/faktor lain yang memang tidak dijelaskan dalam penelitian ini.

\footnotetext{
${ }^{22}$ Kusumaningtuti S. Soetiono., Literasi dan Inklusi, hlm. 7

${ }^{23}$ Susie Suryani dan Surya Ramadhan; “Analisis Literasi Keuangan Pada Pelaku Usaha Mikro di Kota Pekanbaru”, https://journal.ipm2kpe.or.id/index.php/COSTING/article/view/67/3, diakses pada Rabu, 3 April 2019 jam 20.16 WIB
} 


\section{DAFTAR BACAAN}

Akmal, Huriyatul dan Yogi Eka Saputra; Analisis Tingkat Literasi Keuangan Mahasiswa FEBI IAIN Imam Bonjol Padang, (Jurnal Ekonomi dan Bisnis Islam), Volume I, Nomor 2.

Antonio M. Syafi'i, Muhammad (ed.). 2006. Bank Syari'ah: Analisis Kekuatan, Kelemahan, Peluang dan Ancaman. Yogyakarta : Ekonisia.

Antonio M. Syafi'i. 2001. Bank Syariah dan Teori ke Praktek. Jakarta: Gema Insani Press.

Azra Azyumardi, Kafrawi Ridwan, dkk (ed.). 2003. Ensiklopedi Islam Jilid I. Jakarta:PT Ichtiar Baru van Hoeve.

Darsono, dkk. 2017. Perbankan Syariah di Indonesia, Kelembagaan dan Kebijakan serta Tantangan de Depan.Jakarta: Rajawali Pers.

Dewan Rahardjo. 1999. Islam dan Transformasi Sosial Ekonomi. Jakarta: Lembaga Studi Agama dan Filsafat.

Diana Djuwita dan Ayus Ahmad Yusuf; Tingkat Literasi Keuangan Syariah di Kalangan UMKM dan Dampaknya terhadap Perkembangan Usaha, http://syekhnurjati.ac.id/jurnal/index.php/amwal/article/view/2837, diakses pada Rabu tanggal 3 April 2019 jam 19.59 WIB.

Djalal Nachrowi dan Hardius Usman. 2002. Penggunaan Teknik Ekonometrika. Jakarta: RajaGrafindo Persada.

https://www.ojk.go.id/id/berita-dan-kegiatan/siaranpers/Documents/Pages/Siaran-Pers-OJK-Indeks-Literasi-dan-Inklusi-

Keuangan-Meningkat/pdf diakses pada Rabu, 03 April 2019, Jam 20.37 WIB.

Ismail. 2011. Perbankan Syariah. Jakarta: Prenadamedia Group.

Khotibul Umam. 2016. Perbankan Syariah; Dasar-dasar dan Dinamika Perkembangannya di Indonesia. Jakarta: PT. RajaGrafindo Persada.

KuncoroMudrajat. 2009. Metode Riset Untuk Bisnis dan Ekonomi. Yogyakarta: Erlangga.

Mansur. 2016. Modul Praktikum EVIews: Analisis Regresi Linier Berganda Menggunakan Eviews. Jakarta: Fakultas Ekonomi Universitas Borobudur.

Muhammad Akhyar Adnan, dkk ; Pemahaman dan Akseptansi Para Bankir Bank Syariah dan Manajemen Lembaga Keuangan Syariah Terhadapa Pendekatan Economic Value Of Time untuk Produk Mrabahah" Kiat Jurnal Ekonomi, Manajemen dan Akuntansi, Fak, Ekonomi UIR, Vol 23 No.2 Desember 2014.

Mustika Widowati dan Winarto; "Literasi Keuangan Pelaku UMKM Kota Semarang”,http://jurnal.poliupg.ac.id/index.php/infak diakses pada Rabu tanggal 3 April 2019 jam 19.50 WIB.

Narbuko Cholid \& Achmadi A. 2013. Metodologi Penelitian. Jakarta: Bumi Aksara.

Nurul Huda, dkk. 2016. Ekonomi Makro Islam; Pendekatan Teoritis. Jakarta : Prenadamedia Group.

Setiawan \& Dwi Endah Kusrini. 2010. Ekonometrika. Yogyakarta: CV. Andika Offset. 
Soetiono. S Kusumaningtuti dan Cecep Setiawan. 2018. Literasi dan Inklusi Keuangan Indonesia, Depok: Rajawali Pers.

Sugiyono. 2005. Metode Penelitian Bisnis. Bandung: Alfabeta.

Sugiyono. 2014. Cara Mudah Menyusun Skripsi, Tesis dan Disertasi. Bandung : Alfabeta.

Sugiyono. 2017. Metode Penelitian Kombinasi (Mixed Methods). Bandung: Alfabeta.

Sukardi. 2008. Metode Penelitian Pendidikan : Kompetensi dan Prakteknya. Jakarta: PT. Bumi Aksara.

Suliyanto. 2011. Ekonometrika Terapan-Teori dan Aplikasi dengan SPSS. Yogyakarta: CV Andi Offset.

Supriadi, J. 2010. Ekonometrik. Bogor: Ghalia Indonesia.

Supriady Edy. 2014. SPSS + AMOS. Jakarta: Inmedia.

Susie Suryani dan Surya Ramadhan; “Analisis Literasi Keuangan Pada Pelaku

Syahza Almasdi. 2014. Metodologi Penelitian. Pekanbaru: UR Press.

Trianto Budi. 2015. Riset Modeling. Pekanbaru: Adh-Dhuha Institute.

Undang-Undang Nomor 21 Tahun 2008 tentang Perbankan Syariah.

Undang-Undang Negara Republik Indonesia Nomor 20 Tahun 2018 tentang Usaha Mikro, Kecil dan Menengah.

Usaha Mikro di Kota Pekanbaru”,

https://journal.ipm2kpe.or.id/index.php/COSTING/article/view/67/3, diakses pada Rabu, 3 April 2019 jam 20.16 WIB.

WidarjonoAgus. 2010. Analisis Statistik Multivariat Terapan dengan Program SPSS, AMOS, dan SMARTPLS. Yogyakarta: UUP STIM YKPN.

Yosal Iriantara. 2009. Literasi Media. Bandung: Simbiosa Rekatama Media. 